\title{
ASSESSMENT OF COLOR OF MEAT USING THE METHOD OF COMPUTER COLORIMETRY
}

\author{
Oksana Petrusha \\ Department of Foodstuff Expertise \\ National University of Food Technologies \\ 68 Volodymyrska str., Kyiv, Ukraine, 01601 \\ petrushaoo@ukr.net \\ Alexandra Niemirich \\ Department of Technology of Nutrition and Catering Business \\ National University of Food Technologies \\ 68 Volodymyrska str., Kyiv, Ukraine, 01601 \\ avnemirich@mail.ru
}

\begin{abstract}
In the article is considered a possibility to use the accessible modern digital technique: flatbet scanners, digital photocameras and web-cameras for determination of color of foodstuff.

The offered method allows get the digital image of studied sample and count information about the values of color coordinates of its every pixel that characterizes the color of meat half-finished product such as meat powder. The assessment of this raw material was carried out in dry and restored state.

At measurement of color coordinates of the meat powders in native state there was determined the method of sample preparation for getting the mean value of color with the least standard deviation $\sim 20 \%$. Thus, according to the studies, the sample of dry meat half-finished product must be reduced to fragments less than $0,2 \mathrm{~mm}$.

Availability of this method allows use it for assessment of the quality of dry meat half-finished products according to color parameter.
\end{abstract}

Keywords: color coordinates, computed colorimetry, dry meat half-finished product, analysis of image, yellowness index.

\section{Introduction}

According to traditional interpretation, color it is a characteristic of luminous stimulus that creates certain visual perception [1]. From the other side, color is subjective characteristic of the light, it reflects the ability of human eye to recognize the length of wave of electromagnetic radiation in visible spectrum with wave length $360 . .780 \mathrm{~nm}$ [2].

In practice the color of most raw material and ready production is determined organoleptically [3]. The sensor method is insufficiently precise because of possible subjectivity of taster's views [4], but this very method gives the best definition of product for consumer. Physical-chemical methods of assessment of coloring are most precise but need the long sample preparation, special equipment and use of expensive reagents [5].

Progressive development of digital technique gave impulse to creation of direction - the method of computer colorimetry, which essence is in assessment of color in the system of color coordinates after analysis of digital images of the studied sample [6-9].

The aim of the work was to carry out an experimental verification of possibility to use the method of computer colorimetry for the control of quality of powdery foodstuff. For attaining this aim it is necessary to solve the following problems: to study the color of powders from the meat row materials dried by the different methods, in dry and restored state using computer colorimetry.

\section{Materials and methods of research}

The essence of the method of computer colorimetry is in digitization of image of studied sample and its further computer processing for the control of production quality on color, fragments form or surface morphology $[9,10]$. This method allows realize the analysis of studied products fast, automatically and objectively. 
On the Fig. 1 is schematically presented the principle of used methodology.

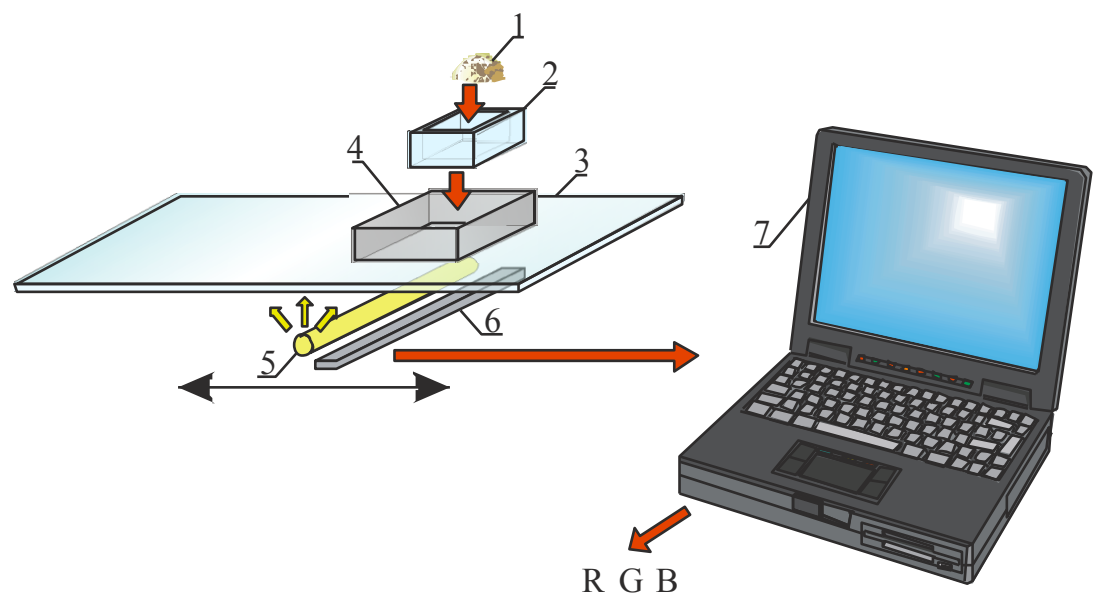

Fig. 1. Scheme of measurement of color coordinates of the studied sample: 1 - studied sample; 2 - cell of transparent glass; 3 - working glass of flatbet scanner; 4 - cell section; 5 - lighting source; 6 - radiations receiver; 7 - personal computer

The samples 1, that is powder or dense substance (powder restored with water) $\sim 5 \mathrm{~g}$ (Fig. 1) were evenly placed in the glass cell 2 (glass does not distort the received digital image), set in the special box - cell section, that allows standardize conditions of sample lighting, exclude highlights and side flares. The cell section is placed on working plane of flatbet scanner 3 Epson Perfection V370 Photo (Indonesia). To get the digital image there was selected the mode of usual scanning of non-transparent objects.

The mobile matrix of analogous-digital converter 6 - Epson matrix CCD (Indonesia), with diode light 5 - LED white (China), transforms photons energy, reflected from the object into eclectic signal that is subjected to digitization.

The coded signal comes on personal computer 7 (minimal requirements: operational system Windows 7 64-bit, main memory $>2$ GB) as digital image with amplification JPG.

Assessment of color of foodstuff can be carried out on the different color models: RGB, CIELab и XYZ.

Description of the color according to RGB model is based on fact that any color consists of the sum of three linearly independent colors - red R, green $-\mathrm{G}$ and blue $-\mathrm{B}$. The white color has the values of coordinates: $\mathrm{R}=255, \mathrm{G}=255$ and $\mathrm{B}=255$, and black $\mathrm{R}=0, \mathrm{G}=0$ and $\mathrm{B}=0$.

CIELab color model has the separate brightness coordinate $-\mathrm{L}$ ( $0 \ldots 100$ units), color area is defined by the values «a» and «b». These values change: «a» - from green «-128» to purple « $+127 »$ and «b» - from blue «-128» to yellow «+127».

$\mathrm{XYZ}$ color model is a unified system that determines color of object as three-dimensional vector coordinates.

It must be noted, that wide list of applied computer programs (for example, Colorlab, Microsoft Word 97-2003, Epson Scan - program that is attached to scanner, CorelDraw and others) has in its content functional possibility for reading color coordinates in one or another systems. The recalculation in several coordinate systems allows choose such coordinate system that is more sensitive to the change of studied product.

For analysis of the color of received digital images was applied program, written in MathCad environment, distributing every pixel of image in digital values of coordinates in RGB system. Synchronously it was carried out the recalculation of color from RGB model in CIELab and XYZ using CorelDraw and ColorLab programs respectively [11].

At that the pixels body or mean values of coordinates of selected part of image can be analyzed (Fig. 2). 


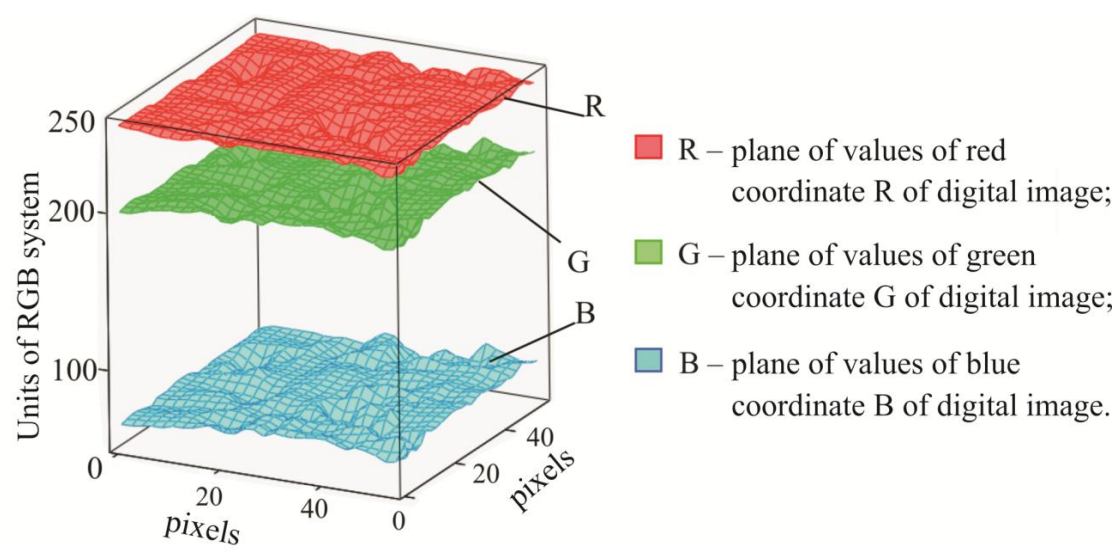

Fig. 2. Value of constituent coordinates of pixels body of digital image of studied sample

For assessment of color are also applied such parameters as saturation $\mathrm{C}_{\mathrm{ab}}(1)$ :

$$
\mathrm{C}_{\mathrm{ab}}=\sqrt{(\mathrm{a})^{2}+(\mathrm{b})^{2}} \text { units, }
$$

where $\mathrm{a}$ and $\mathrm{b}$ - values of coordinates in CIELab system, units; Y - yellowness index [12] (2):

$$
\mathrm{Y}=100 \frac{(1.28 \cdot \mathrm{x}-1.06 \cdot \mathrm{z})}{\mathrm{y}} \text { units, }
$$

where $\mathrm{x}, \mathrm{y}, \mathrm{z}$ - color characteristics of studied object.

The aforesaid parameters give additional information about the color of image. For example, saturation characterizes intensity of coloring of the studied sample, yellowness index - rated parameter that is agreed with visual perception for samples, in which appeared the yellow (positive index) or blue (negative index) tint.

\section{1. Experimental procedures}

At experimental procedures were studied the meat half-finished products, namely the dried beef. There were selected samples, received by the different methods of drying: with mixed heat supply and traditional [13] (for Ukrainian territory) convective drying (Fig. 3). After assessment of color of powders there was carried out their restoration with water: to the one share of dry meat were added 3 shares of water of $20^{\circ} \mathrm{C}$ and their color was measured in 30 minutes.

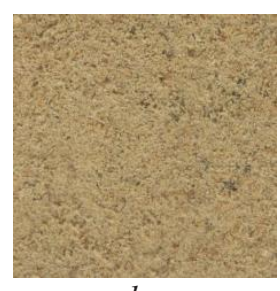

$d r y$

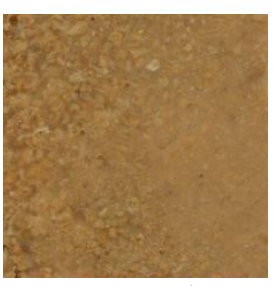

restored

$a$

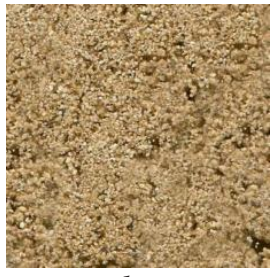

$d r y$

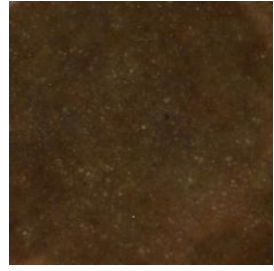

restored

$b$

Fig. 3. Digital images of meat samples: $a$ - sample received by drying with mixed heat supply and $b$ - sample received by convective drying

The meat dried at mixed heat supply is realized on market in granulated form as opposite to the friable state of meat of convective drying. That is why there was carried out the study of different variants of sample preparation of dried meat. It was established, that with increase of size of fragments of meat powder the standard deviation (deviation from the mean value shows how large are the limits of changes of brightness values of image) increases: thus for fragment with mean size $\varnothing=4,5 \mathrm{~mm}$ the standard deviation is $\sim 42 \%$, for fragments $\varnothing=3,0 \mathrm{~mm}-38 \%$ and for powder 
with $\varnothing=0,25 \mathrm{~mm}-18 \%$. That is why it was offered for redpoducibility of the method of computer colorimetry to carry out the reduction of analyzed sample to the powder state. Such sample preparation allows get the real values of color of the sample.

\section{Results of research}

The received digital images of the meat half-finished product in native and restored with water states, assessed on coordinate values in RGB, CIELab and XYZ systems and also the rate values of saturation and yellowness index are presented in Table $\mathbf{1}$.

\section{Table 1}

Characteristics of the samples of meat half-finished materials in native and restored state in RGB, CIELab and XYZ color models

\begin{tabular}{|c|c|c|c|c|c|c|c|c|c|c|c|}
\hline \multirow{3}{*}{ Samples } & \multicolumn{9}{|c|}{ Color coordinates, units } & \multirow{4}{*}{$\begin{array}{l}\text { Saturation, } \\
\mathrm{C}_{\mathrm{ab}} \text { units }\end{array}$} & \multirow{4}{*}{$\begin{array}{l}\text { Yellowness } \\
\text { index, Y units }\end{array}$} \\
\hline & \multicolumn{3}{|c|}{ RGB } & \multicolumn{3}{|c|}{ CIELab } & \multicolumn{3}{|c|}{$\mathbf{X Y Z}$} & & \\
\hline & $\mathbf{R}$ & $\mathbf{G}$ & B & $\mathbf{L}$ & $\mathbf{a}$ & B & $\mathbf{X}$ & $\mathbf{Y}$ & $\mathbf{Z}$ & & \\
\hline \multicolumn{10}{|c|}{ Dry powders } & & \\
\hline Meat with mixed heat supply & 169 & 145 & 103 & 62 & 5 & 26 & 30,64 & 30,40 & 13,16 & 701,00 & 83,12 \\
\hline Meat of convective drying & 170 & 142 & 98 & 61 & 6 & 28 & 29,27 & 29,25 & 11,85 & 820,00 & 85,14 \\
\hline \multicolumn{12}{|c|}{ Restored powders } \\
\hline Meat with mixed heat supply & 153 & 112 & 62 & 51 & 12 & 35 & 20,99 & 19,27 & 5,38 & 1369,0 & 109,83 \\
\hline Meat of convective drying & 67 & 48 & 27 & 22 & 7 & 17 & 3,48 & 3,52 & 1,18 & 338,0 & 104,10 \\
\hline Control - boiled meat & 198 & 177 & 154 & 74 & 5 & 15 & 46,80 & 46,70 & 28,40 & 250,00 & 63,81 \\
\hline
\end{tabular}

Experimentally received data (Table 1) of the meat powders indicate identity of their color in dry state. According to this, it can be recommended to control the quality of this raw material on parameters of color of dried meat in set limits: $R=165 \ldots 175$ units, $G=140 \ldots 150$ units and $B=95 \ldots 105$ units; $\mathrm{L}=60 \ldots 63$ units, $\mathrm{a}=4 \ldots .7$ units and $\mathrm{b}=25 \ldots .30$ units and $\mathrm{X}=28 \ldots .31$ units, $\mathrm{Y}=28 \ldots 31$ units and $\mathrm{Z}=11 \ldots 14$ units in correspondent color systems. At that the yellowness index is $\sim 84$ units. The yellowness index that complexly includes the values of color coordinates can be selected as the main parameter of color of dry meat powder.

The color of meat is conditioned by myoglobin pigment that changes under the influence of several factors and as a result changes the color of meat products.

The different processes of pigments changes flows depending of method of production of meat half-finished product. That is why at comparison of values of coordinates of color of restored and boiled (analyzed as control sample) meat samples took place the clearly observed difference. The yellow index for boiled beef was $\sim 64$ units unlike the restored samples with more than 100 units.

The color of restored meat gives possibility to assess the method of its drying. Analysis of color of restored meat powders allows made conclusion that the difference of processing method influences the change of meat pigments, because the values of color coordinates are differ. Thus, the meat powder, received by convective drying has significantly more dark color than the other sample (dried by the method with mixed heat supply) that is proved by the less values of RGB coordinates and L brightness.

In further it is planned to carry out the study of influence of the factor of meat processing on kinetics of change of its pigments at getting the meat half-finished products and their use in preparation of ready production.

\section{Conclusions}

The offered method of computer colorimetry gives possibility to control the half-finished products on color parameter. The color value of dry meat must be normalized by the value of yellowness index in limits $\mathrm{Y}=84 \pm 1,5$ units. This parameter gives a possibility to take into account the change of all color coordinates for dry meat half-finished product. For granulated products must be carried out the preliminary reduction to the size of fragments less than $0,2 \mathrm{~mm}$. Such preliminary 
stage allows assess the color of product by analysis of the digital image with the least value of standard deviation.

For identification of meat, received by the different methods of drying, it must be studied the kinetics of pigments change depending on such factors: temperature, air presence and effect duration.

\section{References}

[1] Ohta, N., Robertson, A. (2005). Colorimetry: Fundamentals and Application. Wiley, 350.

[2] Hunt, R., Pointer, M. (2011). Measuring Colour. 4th Edition. Wiley, 492.

[3] Olabi, A., Jinjarak, S., Jiménez-Flores, R., Walker, J. H., \& Daroub, H. (2015). Compositional and sensory differences of products of sweet-cream and whey buttermilk produced by microfiltration, diafiltration, and supercritical CO21. Journal of Dairy Science, 98(6), 3590-3598. doi:10.3168/jds.2014-9141

[4] Lim, J. (2011). Hedonic scaling: A review of methods and theory. Food Quality and Preference, 22(8), 733-747. doi:10.1016/j.foodqual.2011.05.008

[5] Lebuhov, V.I., Okara, A.I., Pavlyuchenkova L.P. (2012). Fiziko-himicheskie metodyi issledovaniya. Saint Peterburg: Izdatelstvo «Lan», 480.

[6] Chebotarev, A. N., Snygur, D. V., Bevzyuk, E. V., Efymova, Y. S. (2014). Analyz tendencyy razvytyya metodov xymycheskoj czvetometryy. Metody y ob'ekty hymycheskogo anlyza, 9 (1), 4-11.

[7] Afshari-Jouybari, H., \& Farahnaky, A. (2011). Evaluation of Photoshop software potential for food colorimetry. Journal of Food Engineering, 106 (2), 170-175. doi:10.1016/j.jfoodeng.2011.02.034

[8] Valous, N. A., Mendoza, F., Sun, D.-W., Allen, P. (2009). Colour calibration of a laboratory computer vision system for quality evaluation of pre-sliced hams. Meat Science, 81(1), 132-141. doi:10.1016/ j.meatsci.2008.07.009

[9] Swapnil, S. M., Dale, M. P. (2016). Computer vision based fruit detection and sorting system. Special issue on international journal of electrical, Electronics and computer systems, For $3^{\text {rd }}$ National conference on advancements in communication, Computing and electronics technology, Pune, 12-15.

[10] Shapyrov, L., Stokman, Dzh. (2006). Kompyuternoe zrenye. Moscow: BYNOM, 752.

[11] Vinnov, O. S., Mayevska, T. M., Zasyekin, D. A. (2013). Sposib vymiryuvannya koloru harchovyh produktiv. pat. 82347, MPK G01N 33/02, G01N 33/12, zayavnyk i patentovlasnyk Nacionalnyj universytet bioresursiv i pryrodokorystuvannya Ukrayiny, 25.07.2013, 14, 2.

[12] Ishtvan, Ye. O. (2013). Kolorymetriya, matematychni osoblyvosti procesu obchyslennya kolirnyh harakterystyk zrazka dlya realizaciyi ekspres metodu. Aktualni problemy rozvytku harchovyh vyrobnycztv, restorannogo ta gotel 'nogo gospodarstv i torgivli, Kuiv: KhDUKhT, 112-114.

[13] Atanazevich, V. I. (2000). Sushka pischevyih produktov. Moscow: DeLi, 296. 